\title{
Right time, right place: the temporal regulation of developmental gene expression
}

\author{
Sophia A. Praggastis and Carl S. Thummel \\ Department of Human Genetics, University of Utah School of Medicine, Salt Lake City, Utah 84112, USA
}

\begin{abstract}
Many studies have focused on defining the critical transcription factors that specify tissue morphogenesis and differentiation. Our understanding of how these spatial regulators are deployed in the proper temporal order, however, has remained less clear. In this issue of Genes \& Development, Uyehara and colleagues (pp. 862-875) provide new insights into the mechanisms by which temporal and spatial regulators are coordinated to control Drosophila wing development during metamorphosis.
\end{abstract}

A mere 50 years ago, our understanding of eukaryotic gene regulation was restricted to rare biological phenomena that allowed us to directly visualize genes caught in the act of transcription. Nowhere was this more dramatic than in the giant polytene chromosomes of Drosophila, where waves of locally decondensed chromatin, visualized as giant puffs, appear and disappear as the animal enters metamorphosis (Becker 1962). Through a series of detailed and elegant studies, Michael Ashburner and colleagues at the University of Cambridge focused their efforts on these transcriptional cascades, providing a foundation for our understanding of eukaryotic gene regulation. Their pioneering work showed that the insect steroid hormone ecdysone induces a cascade of early and late puffs, leading to the classic Ashburner model for the temporal regulation of polytene chromosome puffing (Ashburner et al. 1974). Remarkably, almost all of the regulatory interactions predicted by this work were confirmed at the molecular level through studies in the laboratory of D.S. Hogness (White et al. 1997) at Stanford University and by his trainees (Crossgrove et al. 1996; Li and Bender 2000; Thummel 2001).

As studies of transcriptional control expanded into other areas, however, the focus shifted away from temporal regulation and toward studying spatial patterns of gene expression. These efforts centered on defining the function of "master" regulators that specify tissue and cell identi-

[Keywords: temporal gene regulation; open chromatin; ecdysone; pioneer transcription factor; genomics]

Corresponding author: carl.thummel@genetics.utah.edu

Article is online at http://www.genesdev.org/cgi/doi/10.1101/gad.301002. 117. ty. Although it is clear that these critical spatial determinates must be coordinated with temporal signals to ensure the proper progression of development, few studies have addressed the molecular mechanisms that underlie this control.

In this issue of Genes \& Development, Uyehara et al. (2017) return to a genome-wide perspective for studying changes in gene expression during development-not involving the larval polytene chromosomes but rather focusing on temporal changes in open chromatin sites in the developing Drosophila wing. Earlier work from this laboratory showed that chromatin isolated from different Drosophila appendages shares many open sites between tissues and that these patterns change in a coordinated manner during development (McKay and Lieb 2013). This study raised the possibility that temporal regulators might play an important role in establishing the appropriate spectrum of open chromatin sites that defines the transcriptional state at each stage in the life cycle. To test this model, the investigators examined the transcriptional profile of the fly wing during three stages of development that span the first half of metamorphosis as well the distribution of open chromatin sites using formaldehyde-assisted identification of regulatory elements (FAIRE) combined with sequencing (FAIRE-seq). Not surprisingly, thousands of genes change their expression during this time, while approximately one-third of open chromatin sites across the genome either appear or disappear. Interestingly, these dynamic changes in chromatin accessibility correlate with changes in neighboring gene expression, suggesting that they contribute to specific gene regulation. To examine this possibility, the investigators focused on temporally dynamic open chromatin regions that lie upstream of three genes that are required for wing development: tenectin, nubbin, and broad. In each case, short genomic fragments that correspond to these sites act as temporally specific enhancers that drive GFP

(C) 2017 Praggastis and Thummel This article is distributed exclusively by Cold Spring Harbor Laboratory Press for the first six months after the full-issue publication date (see http://genesdev.cshlp.org/site/misc/ terms.xhtml). After six months, it is available under a Creative Commons License (Attribution-NonCommercial 4.0 International), as described at http://creativecommons.org/licenses/by-nc/4.0/. 
expression in the appropriate region of the developing appendage.

The investigators then consider the possibility that ecdysone contributes to this temporal progression given its central role in controlling wing morphogenesis during pupal stages (Fristrom and Fristrom 1993). They showed that waves of ecdysone-regulated transcription factors are expressed in the developing wing, paralleling the Ashburner model and the known transcriptional changes in larval tissues at these stages. Of particular interest, they noted that predicted binding motifs for the ecdysone-induced transcription factor E93 are overrepresented within temporally dynamic open chromatin sites. Given its known role in wing development during metamorphosis (Mou et al. 2012), the investigators focused their final studies on this factor. Using ChIP-seq /chromatin immunoprecipitation [ChIP] combined with high-throughput sequencing), they showed that half of the chromatin regions that either open or close during their time course contain bound E93 protein, suggesting that these regions act as upstream E93regulated enhancer elements. Consistent with this, many dynamic changes in chromatin accessibility depend on E93 function. Unexpectedly, however, some sites fail to close properly in the absence of E93, while other sites fail to open, demonstrating multiple modalities for E93 activity.

Finally, the investigators returned to their three transgenic reporter lines by showing that each of these enhancer elements contains bound E93 protein and that reporter expression in the wing is dependent on E93 function. Moreover, the dynamic changes in chromatin configuration at each of the three endogenous enhancer elements is dependent on E93. However, these regions respond to a loss of E93 in different ways. E93 can either act like a "pioneer" transcription factor by opening chromatin accessibility, reduce chromatin accessibility, or act as a conventional transcription factor in the absence of detectable changes in chromatin configuration.

Although it has long been known that the temporal and spatial regulation of gene expression must be coordinated during development, the mechanisms have remained unclear. This study supports the model that ecdysone regulation of E93 plays an important role in controlling gene expression in the Drosophila wing-both opening chromatin at late-acting enhancers and closing chromatin at early-acting enhancers. In addition, this work paves the way for future studies aimed at better characterizing this critical level of developmental gene regulation. In particular, it remains unclear how changes in ecdysone titer are linked to dynamic changes in chromatin configuration over time. It would be interesting to examine the effects of disrupting the ecdysone pulses at the onset of metamorphosis on enhancer activity, chromatin configuration, and wing development. Similarly, more work is needed to understand the mechanisms by which E93 regulates gene expression. Although the investigators used informatics to predict an E93-binding site, this DNA sequence has not yet been defined in vitro or in vivo. Similarly, a direct prediction of this work is that E93-dependent enhancer elements contribute to specific domains of temporally regulated gene expression in the wing - a hypothesis that is now testable using CRISPR/Cas9 technology. Finally, the remarkable discovery that E93 can either open chromatin, close chromatin, or act as a conventional transcription factor raises intriguing questions regarding its mechanisms of action.

The field of developmental gene regulation has come a long way since the discovery of polytene chromosome puffs and the central role of ecdysone in coordinating the temporal progression of gene expression during development. This report makes it clear that we are at the dawn of a new era that brings these studies back to a genomewide level to understand how temporal and spatial cues are integrated to drive tissue development forward through time.

\section{Acknowledgments}

Research in the Thummel laboratory is supported by the National Institutes of Health (DK075607 and DK108941).

\section{References}

Ashburner M, Chihara C, Meltzer P, Richards G. 1974. Temporal control of puffing activity in polytene chromosomes. Cold Spring Harb Symp Quant Biol 38: 655-662.

Becker H. 1962. Die puffs der speicheldrüsenchromosomen von Drosophila melanogaster. Chromosoma (Berlin) 13: 341.

Crossgrove K, Bayer CA, Fristrom JW, Guild GM. 1996. The Drosophila Broad-complex early gene directly regulates late gene transcription during the ecdysone-induced puffing cascade. Dev Biol 180: 745-758.

Fristrom D, Fristrom JW. 1993. The metamorphic development of the adult epidermis. In The development of Drosophila melanogaster (ed. Bate M, Martinez Arias A), pp. 843-897. Cold Spring Harbor Laboratory Press, Cold Spring Harbor, NY.

Li T, Bender M. 2000. A conditional rescue system reveals essential functions for the ecdysone receptor (EcR) gene during molting and metamorphosis in Drosophila. Development 127: 2897-2905.

McKay DJ, Lieb JD. 2013. A common set of DNA regulatory elements shapes Drosophila appendages. Dev Cell 27: 306-318.

Mou X, Duncan DM, Baehrecke EH, Duncan I. 2012. Control of target gene specificity during metamorphosis by the steroid response gene E93. Proc Natl Acad Sci 109: 2949-2954.

Thummel CS. 2001. Molecular mechanisms of developmental timing in C. elegans and Drosophila. Dev Cell 1: 453-465.

Uyehara CM, Nystrom SL, Niederhuber MJ, Leatham-Jensen M, Ma Y, Buttitta L, McKay DJ. 2017. Hormone-dependent control of developmental timing through regulation of chromatin accessibility. Genes Dev (this issue). doi: 10.1101/ gad.298182.117.

White KP, Hurban P, Watanabe T, Hogness DS. 1997. Coordination of Drosophila metamorphosis by two ecdysone-induced nuclear receptors. Science 276: 114-117. 


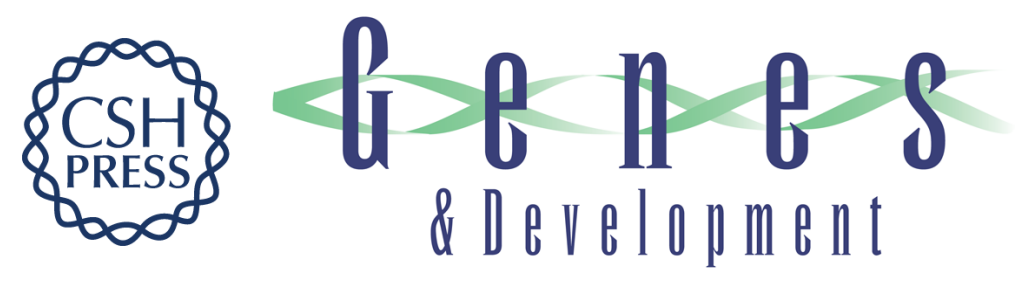

\title{
Right time, right place: the temporal regulation of developmental gene expression
}

\author{
Sophia A. Praggastis and Carl S. Thummel
}

Genes Dev. 2017, 31:

Access the most recent version at doi:10.1101/gad.301002.117
Related Content Hormone-dependent control of developmental timing through regulation of chromatin accessibility
Christopher M. Uyehara, Spencer L. Nystrom, Matthew J. Niederhuber, et al.
Genes Dev. May, 2017 31: 862-875

References This article cites 9 articles, 5 of which can be accessed free at:

http://genesdev.cshlp.org/content/31/9/847.full.html\#ref-list-1

Articles cited in:

http://genesdev.cshlp.org/content/31/9/847.full.html\#related-urls

Creative This article is distributed exclusively by Cold Spring Harbor Laboratory Press for the first

Commons

License

six months after the full-issue publication date (see

http://genesdev.cshlp.org/site/misc/terms.xhtml). After six months, it is available under a

Creative Commons License (Attribution-NonCommercial 4.0 International), as described at http://creativecommons.org/licenses/by-nc/4.0/.

Email Alerting

Receive free email alerts when new articles cite this article - sign up in the box at the top

Service right corner of the article or click here.

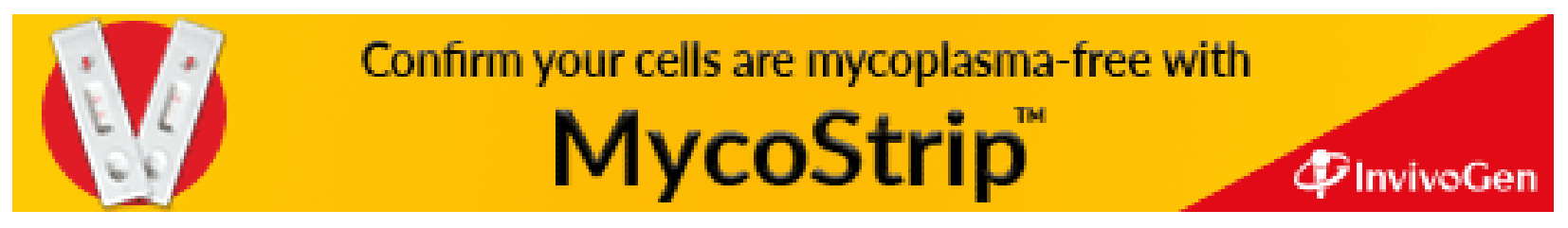

